\title{
Incidence Model of Intestinal Helminthiasis Infections in Toddler with Nutritional Problems in Central Kupang District, Kupang Regency
}

\author{
Wilhelmus Olin ${ }^{1}$, Rafael Paun ${ }^{1} \&$ Maria F. Vinsensia. D.P.K Niron ${ }^{1}$ \\ ${ }^{1}$ Health Polytechnic of Health Ministry, Kupang, Indonesia \\ Correspondence: Wilhelmus Olin, Health Polytechnic of Health Ministry, Kupang, Indonesia.
}

Received: January 7, 2021 Accepted: February 1, 2021 Online Published: March 5, 2021

doi:10.5539/gjhs.v13n4p62 URL: https://doi.org/10.5539/gjhs.v13n4p62

\begin{abstract}
The prevalence of nutritional problems for infants under 5 years of age (toddlers) in East Nusa Tenggara reaches $40.3 \%$, the highest compared to other provinces in Indonesia. This figure is above the national nutritional problem prevalence of $29.6 \%$. One of the factors that causes the nutritional status of children under five is an intestinal worm infection. The purpose of this study was to determine the incidence model of intestinal worm infection in children under five with nutritional problems in Central Kupang District, Kupang Regency. Quantitative research method with cross sectional study design. The sample size of this study is a total population of 80 children under five and the independent variables are environmental sanitation and personal hygiene and the dependent variable is malnutrition and low nutrition status. The data collection technique was carried out by weighing to determine the nutritional status and followed by fecal examination to identify worm eggs and analyzed by multiple logistic regression. The results showed that the incidence of intestinal worm infections was $42 \%$ of children under five with nutritional problems. The results of statistical tests showed that there was an effect of snacking habits $p$ value $=0.024$ and food storage $\mathrm{p}$ value $=0.033$. The conclusion is that the incidence of intestinal worm infections in children under five with nutritional problems is influenced by eating habits and opened food storage.
\end{abstract}

Keywords: infection, helminthiasis, habit, sanitation, environment

\section{Introduction}

Community nutritional status describes the condition of food availability and nutrition that meets health requirements derived from plants, animals and fish and food processed materials that meet standards. Community nutritional status can be measured through indicators such as low birth weight (LBW), nutritional status of children under five, nutritional status of fertile women with chronic energy deficiency, and disorders due to iodine deficiency (IDD). The nutritional status of children under five is measured based on age, body weight (BW), and height $(\mathrm{H})$. The weight and height variables are presented in the form of 3 anthropometric indicators, namely body weight for age (BW/A), height for age (H/A) and body weight according to height (BW/H). The weight/age indicator provides an overview of nutritional status which is general, not specific.

The high and low prevalence of malnutrition and low nutrition indicates the presence or absence of nutritional problems in children under five, but does not give an indication whether these nutritional problems are chronic or acute. Indicators that describe the nutritional status of the community include the percentage of neonates visits, percentage of infant visits, percentage of LBW handled, under-fives with malnutrition and nutrition-prone districts.

The nutritional status of children under five is an indicator that describes the level of community welfare. One way of assessing the nutritional status of toddlers is by anthropometry which uses the body weight index for age (BW/A). The categories used were over nutrition (Z-score $>+2$ Standard Deviation - SD); Good nutrition (z-score-2 SD to +2 SD); Low nutrition (z-score <-2 SD to -3 SD); Malnutrition (z-score <-3 SD).

Data on Nutrition Problems in Indonesia show that around 37\% (9 million) children in East Nusa Tenggara Province who experience nutritional problems or as many as 319,100 children (Basic Health Research - Riskesdas., 2013). Although the prevalence of nutritional problems in NTT in (Rikesdas, 2018) shows a decrease of 30.8\%, NTT Province has a high percentage of children under five with nutritional problems, namely $42.6 \%$. The prevalence of nutritional problems for infants under 5 years of age (toddlers) in East Nusa Tenggara reaches 40.3\%, the highest compared to other provinces in Indonesia. This figure is above the national nutritional problem 
prevalence of $29.6 \%$. The prevalence of nutritional problems in NTT consisted of $18.0 \%$ very short babies and $22.3 \%$ short babies.

Nutritional status is caused by multidimensional factors, including poor nutrition care practices, including a lack of knowledge of mothers about health and nutrition before and during pregnancy and after delivery (Ramayulis et al.,, 2018).

One of the factors that affect the nutritional status of children under five is intestinal worm infection in children under five. According to the WHO (World Health Organization) it is known that the incidence of worms in the world is still high, namely 1 billion people are infected with Ascaris lumbricoides worms, 795 million people are infected with Trichuris trichiura and 740 million people are infected with hookworms.

The results of the study in Southwest Sumba Regency showed that there was an effect of STH worm infection on anemia in elementary school children, where the positive STH stool examination results were $42(40.0 \%)$ and 63 $(60.0 \%)$ negative. The types of STH worms were known to be Ascaris lumbricoides (31.0\%), Trichuris trichiura 9 (21.4\%), Hookworm Ancylostoma duodenale 1 (2.4\%), Hookworm Necator americanus 3 (7.1\%), mix AL and TT 16. (38.1\%) (Paun et al.,, 2019).

Environmental and behavioral factors influence the incidence of worms in children. Playing behavior is an important thing to consider in relation to the sanitary conditions of the home environment. A good sanitary condition of the home environment will certainly provide a sense of security and comfort for children to play. In connection with the habits of children playing on the ground, it is necessary to be aware of the possibility of children being exposed to hookworms which require soil media for their breeding. A chronic worm disease that is influenced by environmental factors and children's behavior (Olin et al., 2019).

In addition to suitable soil and environmental conditions, endemicity is also influenced by the number of eggs that can live to become an infective form and enter the host (host). The more eggs found in the source of contamination (soil, dust, vegetables, etc.), the higher the endemicity in an area. In plantation and mining areas hookworm infections often occur in the people living in the vicinity. Hookworms in their transmission cycle require loose sandy soil, mixed with humus, and protected from direct sunlight. The impact of this worms disease is on children, worms will interfere with the child's ability to learn. In moderate infection it can cause cognitive dysfunction and in adults will decrease work productivity in the long run, this will result in a decrease in the quality of human resources. The process of spreading worms is transmitted through the soil which is often found in elementary school aged children who are still playing with the ground. Soil contamination is the cause of transmission of worm eggs from the soil and into the mouth with food (Irianto, 2009).

There are more cases of worms in children, due to the habit of playing with soil contaminated by worms, children who lack parental attention, low personal hygiene, and poor environmental sanitation conditions. An environment that does not meet health standards is a risk factor for public health problems. These environmental problems include the lack of clean water supply, disposal of feces in any place such as in the soil, gardens, rivers, ponds and others, unsanitary housing conditions, garbage disposal and waste in poor residential areas. In Indonesia, the Province of East Nusa Tenggara (NTT) occupies the third position with a percentage of $27.7 \%$ after Banten province with $60.7 \%$. This shows that the prevalence of worm infections in children is still quite high (Rawina \& Mulyati, 2012).

\section{Method}

This research was conducted in 2020 in Central Kupang District, Kupang Regency, East Nusa Tenggara Province. This type of research is a quantitative study with a cross sectional study design, with a sample size of a total population of 80 children under five. The independent variables of the study were environmental sanitation and personal hygiene and the research variable was intestinal worm infection. The data collection technique was carried out by measuring the height and weight of the children under five and determining the nutritional status as well as conducting fecal examinations in the laboratory and conducting interviews with the mothers of the children and observing the home environment of the children under five. Research data analysis was carried out by bivariate analysis, namely Chi-Square and Multivariate with multiple logistic regression analysis.

\section{Result}

The results showed that the incidence of intestinal worm infections in children under five with malnutrition and malnutrition was $42 \%$, as can be seen in the following figure: 


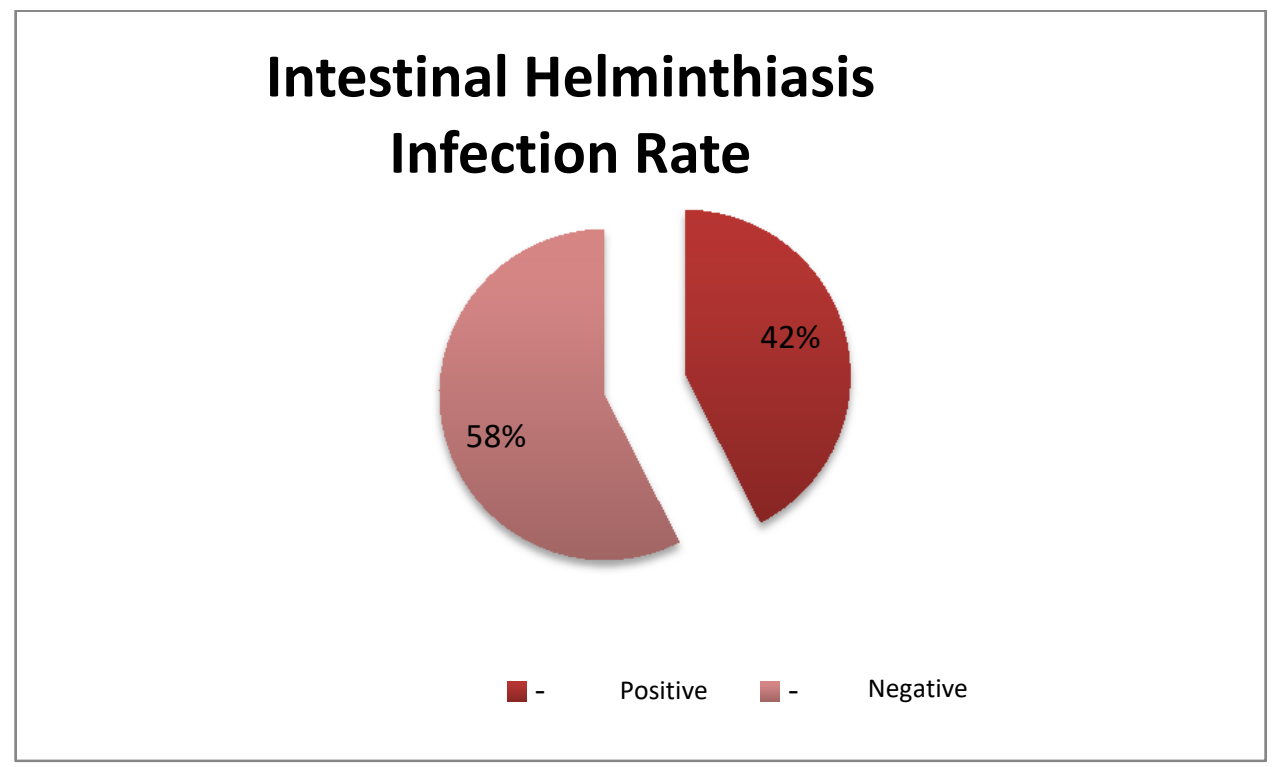

Figure 1. Incidence of intestinal worm infections in children under five with malnutrition and malnutrition

The picture above shows that many (42\%) children under five with malnutrition status are infected with intestinal worms. Types of intestinal worms as shown in the following table.

Table 1. Types of Intestinal Worm Infection

\begin{tabular}{lcc}
\hline Types of Worms & Number & $1 \%$ \\
\hline Ascariasis Lumbricoides & 27 & 79,4 \\
Trichuris Trichura & 2 & 5,9 \\
Ancilos Duodenale & 1 & 2,9 \\
Enterobius Vermicularis & 2 & 5,9 \\
Mix (Asc.L\& Ent.Vermicularis & 1 & 2,9 \\
Mix (Asc.L \& Nec. Amaricanus & 1 & 2,9 \\
Total & 34 & 100 \\
\hline
\end{tabular}

Table 1 above shows that out of 34 children under five who were infected with intestinal worms, most (79.4\%) were Ascariasis Lumbricoides.

\subsection{Effect of Environmental Factors}

Table 2. The Effect of Environmental Factors on Intestinal Worm Infection

\begin{tabular}{|c|c|c|c|c|c|}
\hline \multirow{2}{*}{\multicolumn{2}{|c|}{ Environmental Factors }} & \multicolumn{2}{|c|}{ Intestinal Worm Infection } & \multirow{2}{*}{ Number } & \multirow{2}{*}{ p Value } \\
\hline & & Positive & Negative & & \\
\hline \multicolumn{6}{|l|}{ Latrine } \\
\hline & None & $6(17,6 \%)$ & $6(13,0 \%)$ & $12(15,0 \%)$ & \multirow{2}{*}{0,569} \\
\hline- & Have & $28(82,4 \%)$ & $40(87, \%)$ & $68(85,0 \%)$ & \\
\hline Total & & $34(100 \%)$ & $46(100 \%)$ & $80(100 \%)$ & \\
\hline \multicolumn{6}{|l|}{ Types of Latrine } \\
\hline & Pit latrines & $19(67,9 \%)$ & $24(38,4 \%)$ & $43(63,2 \%)$ & \multirow{2}{*}{0,508} \\
\hline- & Septictank & $9(32,1 \%)$ & $16(40,0 \%)$ & $25(36,8 \%)$ & \\
\hline
\end{tabular}




\begin{tabular}{|c|c|c|c|c|c|}
\hline Total & & $28(100 \%)$ & $40(100 \%)$ & $68(100 \%)$ & \\
\hline \multicolumn{6}{|c|}{ Animal/Cattle } \\
\hline & - $\quad$ Have & $20(58,8 \%)$ & $28(60,9 \%)$ & $48(60,0 \%)$ & \multirow{2}{*}{0,853} \\
\hline & - None & $14((41,2 \%)$ & $18(39,1 \%)$ & $32(40,0 \%)$ & \\
\hline Total & & $34(100 \%)$ & $46(100 \%)$ & $80(100 \%)$ & \\
\hline \multicolumn{6}{|c|}{ Cattle Pen } \\
\hline & - $\quad$ None & $10(52,6 \%)$ & $7(24,1 \%)$ & $17(35,4 \%)$ & \multirow{2}{*}{0,299} \\
\hline & - $\quad$ Have & $9(47,4 \%)$ & $22(75,9 \%)$ & $31(64,6 \%)$ & \\
\hline Total & & $19(100 \%)$ & $29(100 \%)$ & $48(100 \&)$ & \\
\hline \multicolumn{6}{|c|}{ Cattle pen location } \\
\hline & - $\quad$ Inside the house & $0(0,0 \%)$ & $0(0,0 \%)$ & $0(0,0 \%)$ & \\
\hline & - $\quad$ Outside the house & $9(100 \%)$ & $22(100 \%)$ & $31(100 \%)$ & \\
\hline Total & & $9(100 \%)$ & $22(100 \%)$ & $31(100 \%)$ & \\
\hline \multicolumn{6}{|c|}{ Cattle pen-house distance } \\
\hline & $-\quad<20$ meter & $6(66,7 \%)$ & $18(81,8 \%)$ & $24(77,4 \%)$ & \multirow{2}{*}{0,384} \\
\hline & $-\quad>20$ meter & $3(33,3 \%)$ & $4(18,2 \%)$ & $7(22,6 \%)$ & \\
\hline Total & & $9(100 \%)$ & $22(100 \%)$ & $31(100 \%)$ & \\
\hline \multicolumn{6}{|c|}{ Cattle pen condition } \\
\hline & - $\quad$ Dirty & $4(44,4 \%)$ & $4(18,2 \%)$ & $8(26,8 \%)$ & \multirow{2}{*}{0,221} \\
\hline & - $\quad$ Clean & $5(55,6 \%)$ & $18(78,3 \%)$ & $23(74,2 \%)$ & \\
\hline Total & & $9(100 \%)$ & $22(100 \%)$ & $31(100 \%)$ & \\
\hline \multicolumn{6}{|c|}{ Drinking water source } \\
\hline & - $\quad$ River & $1(2,7 \%)$ & $1(2,2 \%)$ & $2(2,5 \%)$ & \multirow{2}{*}{1,000} \\
\hline & - $\quad$ Tap water/Well & $33(97,3 \%)$ & $45(97,8 \%)$ & $78(97,5 \%)$ & \\
\hline Total & & $34(100 \%)$ & $46(100 \%)$ & $80(100 \%)$ & \\
\hline \multicolumn{6}{|c|}{ House floor } \\
\hline & - $\quad$ Soil & $4(11,8 \%)$ & $4(8,7 \%)$ & $8(10,0 \%)$ & \multirow{2}{*}{0,717} \\
\hline & - $\quad$ Stilts/cement/tiles & $30(88,2 \%)$ & $42(91,3 \%)$ & $72(90,0 \%)$ & \\
\hline Total & & $34(100 \%)$ & $46(100 \%)$ & $80(100 \%)$ & \\
\hline \multicolumn{6}{|c|}{ Floor condition } \\
\hline & - Dirty & $8(23,5 \%)$ & $5(10,9 \%)$ & $13(16,3 \%)$ & \multirow{2}{*}{0,219} \\
\hline & - Clean & $26(76,5 \%)$ & $41(89,1 \%)$ & $67(83,8 \%)$ & \\
\hline Total & & $34(100 \%)$ & $46(100 \%)$ & $80(100 \%)$ & \\
\hline \multicolumn{6}{|c|}{ Garbage dump } \\
\hline & - $\quad$ None & $23(67,6 \%)$ & $16(34,8 \%)$ & $39(48,8 \%)$ & \multirow{2}{*}{0,004} \\
\hline & - $\quad$ Have & $11(32,4 \%)$ & $30(65,2 \%)$ & $41(51,2, \%)$ & \\
\hline Total & & $34(100 \%)$ & $46(100 \%)$ & $80(100 \%)$ & \\
\hline \multicolumn{6}{|c|}{ Waste Disposal Facilities } \\
\hline & - $\quad$ None & $31(912 \%)$ & $33(71,7 \%)$ & $64(80,0 \%)$ & \multirow{2}{*}{0,032} \\
\hline & - $\quad$ Have & $3(8,8 \%)$ & $13(28,3 \%)$ & $16(20,0 \%$ & \\
\hline Total & & $34(100 \%)$ & $46(100 \%)$ & $80(100 \%)$ & \\
\hline
\end{tabular}




\begin{tabular}{|c|c|c|c|c|c|c|}
\hline \multicolumn{7}{|c|}{ Agricultural land } \\
\hline & - & Have & $7(20,6 \%)$ & $14(30,4 \%)$ & $21(26,3 \%)$ & \multirow{2}{*}{0,322} \\
\hline & - & None & $27(79,4 \%)$ & $32(69,6 \%)$ & $59(73,8 \%)$ & \\
\hline Total & & & $34(100 \%)$ & $46(100 \%)$ & $80(100 \%)$ & \\
\hline \multicolumn{7}{|c|}{ Agricultural land - House distance } \\
\hline & - & $<50$ meter & $6(17,6 \%)$ & $14(30,0 \%)$ & $20(25,0 \%)$ & \multirow{3}{*}{0,329} \\
\hline & - & $>50$ meter & $2(5,9 \%)$ & $1(2,2 \%)$ & $3(3,8 \%)$ & \\
\hline & - & No land & $26(76,5 \%)$ & $31(67,4 \%)$ & $57(71,3 \%)$ & \\
\hline Total & & & $34(100 \%)$ & $46(100 \%)$ & $80(10050$ & \\
\hline
\end{tabular}

Table 2 above shows that most families of children under five have family latrines, the results of the Chi-Square statistical test $p$ value $0.569>\alpha 0.05$, so there is no effect of having a family latrine on the incidence of intestinal worm infection in children under five with nutritional problems as well as the type of latrine. Most of them were pit latrine, the results of the statistical test $P$ value were $0.508>\alpha 0.05$, so the type of latrine had no effect on intestinal worm infection in children under five.

Most of the families of children under five have animals / livestock, but the results of the statistical test $\mathrm{p}$ value $0.853>\alpha 0.05$, it means that there is no effect of livestock ownership on the incidence of intestinal worm infection in under five children. There are some families who have livestock having a pen, the statistical test results are $\mathrm{p}$ value $0.299>\alpha 0.05$, so there is no effect of livestock pen ownership on the incidence of intestinal worm infection in children under five. The location of the pen is generally outside the house with the distance of the pen in general $<20$ meters from the house, the results of statistical test $p$ value $0.384>\alpha 0.05$, so there is no effect of pen distance on the incidence of intestinal worm infection in children under five. The conditions of the cattle sheds are generally clean, the results of the statistical test are p value $0.221>\alpha 0.05$, so there is no effect of pen conditions on the incidence of intestinal worm infection in children under five.

The source of drinking water used by the family is generally from Tap Water/well, the result of the statistical test is $p$ value $1,000>\alpha 0.05$, so there is no effect of drinking water sources on the incidence of intestinal worm infections in children under five. The floor of the house in general is stilts / cement / tile, the result of statistical test is $p$ value $0.717>\alpha 0.05$, so there is no effect of house floor on the incidence of intestinal worm infections in children under five. Floor conditions are generally clean, statistical test results $p$ value $0.219>\alpha 0.05$, so there is no effect of floor conditions on the incidence of intestinal worm infections in children under five.

Garbage dumps in families of children with intestinal worm infections generally do not exist, the results of statistical tests are $p$ value $0.004<\alpha 0.05$, so there is an effect of garbage dumps on the incidence of intestinal worm infections in children under five. Likewise, in general, families do not have waste disposal facilities, the results of the statistical test are $\mathrm{p}$ value $0.032<\alpha 0.05$, so there is an effect of waste disposal facilities on intestinal worm infections in children under five.

Agricultural land is generally not available, statistical test results $p$ value $0.322>\alpha 0.05$, so there is no effect of agricultural land on intestinal worm infections in children under five. Likewise, the distance between agricultural land and houses is generally $<50$ meters, the results of the statistical test $p$ value $0.329>\alpha 0.329$, so there is no effect of the distance of agricultural land on the incidence of intestinal worm infections in children under five. 


\subsection{Effect of Personal Hygiene Factor}

Table 3. Effect of Behavior on Incidence of Intestinal Worm Infection

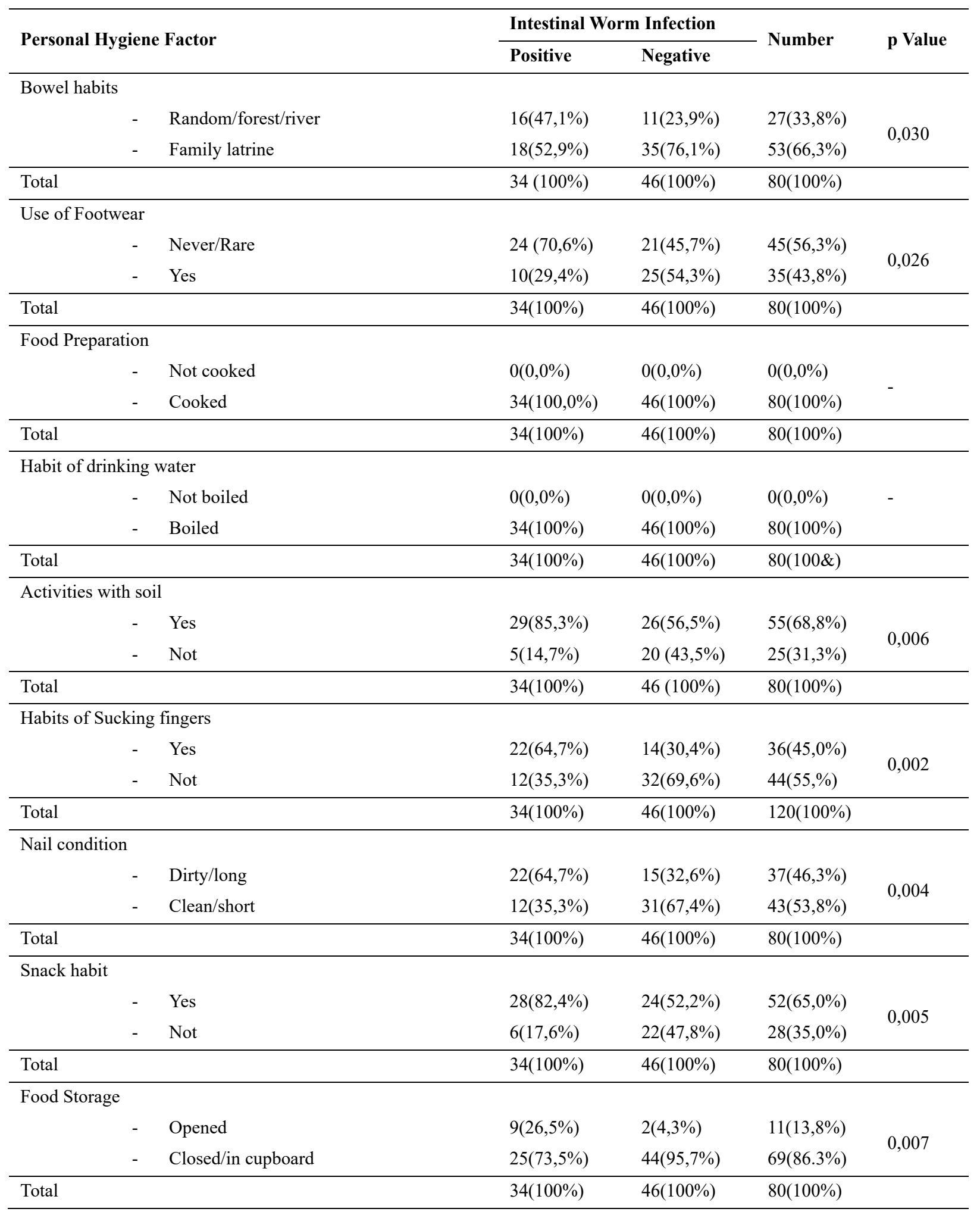

Table 3 above shows the habits of children under five who are infected with intestinal worms defecating partly $(47.1 \%)$ in random places, the results of statistical tests are $p$ value $0.030<\alpha 0.05$, so there is an effect of defecating 
on intestinal worm infections in children under five. The habit of toddlers using footwear is generally not / rare, the result of statistical test is $p$ value $0.026<\alpha 0.05$, so there is an effect of the habit of using footwear on the incidence of intestinal worm infection in children under five. The habit of children under five years of activity (playing) with the soil, statistical test results $\mathrm{p}$ value $0.006<0.05$, so there is an effect of the ability to play with the soil on intestinal worm infections in children under five. Playing behavior related to environmental sanitation conditions is an important thing to pay attention to from a health perspective. In rural community conditions, children tend to play in the yard or garden with their peers. In relation to the habits of children playing on the ground, it is necessary to be aware of the possibility of children being exposed to soil-borne worms that do need soil media for reproduction. According to research conducted by Xiao et al, (2015) in China, it shows that the environment where activities are carried out has a significant relationship with worm infection. Meanwhile, according to Widari's research (2014) in the village of Jagapati Bali, it was shown that the habit of playing did not have a significant relationship with worm infection with a value of $\mathrm{p}=1.00$.

The eating habits of children under five are $100 \%$ cooked, as is the habit of drinking $100 \%$ cooked water. The habit of children under five generally inserts their fingers into their mouths (sucking their fingers), the results of statistical tests are $\mathrm{p}$ value $0.002<\alpha 0.05$, so there is an effect of the habit of putting their fingers in the mouth on the incidence of intestinal worm infections in children under five. Likewise, the nail conditions of children under five, are generally dirty and long, the results of the statistical test $\mathrm{p}$ value $0.004<\alpha 0.05$, so there is an effect of nail conditions on intestinal worm infections in toddlers.

In general, snack habits in children under five, the statistical test results of $p$ value $0.005<\alpha 0.05$, so there is an effect of eating habits on intestinal worm infections in toddlers. Furthermore, family habits do not cover cooked food, the results of statistical test $p$ value $0.007<\alpha 0.05$, so there is an effect of the habit of closing food on the incidence of intestinal worm infections in children under five..

\subsection{Incidence Model of Intestinal Helminthiasis Infections in Toddler With Nutritional Problems}

Table 4. Final Model of Intestinal Worm Infection

\begin{tabular}{llllll}
\hline Variable & B & P Value & Exp.B & \multicolumn{2}{c}{$95 \%$ CI } \\
\cline { 5 - 6 } & & & & Low & Upper \\
\hline Snack Habit & $-1,253$ & 0,024 & 0,286 & 0,096 & 0,846 \\
Way of Storing Food & $-1,792$ & 0,033 & 0,167 & 0,032 & 0,864 \\
Constant & 1,386 & 0,003 & 4,000 & & \\
\hline
\end{tabular}

Table 4 above shows the results of multiple logistic regression statistical tests the effect of $p$ valye eating habits $0.024<\alpha 0.05$, so there is a significant effect of eating habits on the incidence of intestinal worm infections in children under five with nutritional problems. The Exp B value of 0.286 indicates that the habit of eating snacks is protective against intestinal worm infections, on the other hand, if the habit of eating snacks is limited, the possibility of children under five not experiencing intestinal worm infections is 3.5 times $(1 / 0.286)$ compared to the habits of children's snacks.

The effect of how to store food, the results of multiple logistic regression statistical tests $p$ value 0.167 shows how to store food openly and protectively against intestinal worm infections in children under five with nutritional problems, on the other hand, if the method is to keep it closed or stored in a cupboard, it is possible that the toddler will not experience intestinal worm infection 6 times $(1 / 0.167)$ compared to how to store food openly.

The final model of the incidence of intestinal worm infection in children under five with nutritional problems is as follows:

$$
\mathrm{p}=\frac{1}{e^{-(1,386-1,253(\mathrm{SH})-1,792(\mathrm{WSF}))}}
$$

\section{Keterangan:}

$\mathrm{P}=$ Probability

$\mathrm{e}=$ Epsolon

$\mathrm{SH}=$ Snack habit 
WSF= Way of Storing Food

The model above shows the probability that the incidence of intestinal worm infections in children under five with nutritional problems (malnutrition) is influenced by eating habits and how to store open food simultaneously..

\section{Discussion}

Prevalence is the frequency of old and new diseases that occur in the community in a certain area at a certain time. So that the prevalence of worms is a number that describes the incidence of worm disease in a certain area.

Intestinal worm infections can have a huge impact on health, causing direct or indirect harm. Directly, worms can affect the intake, absorption and metabolism of food into the body. In cumulative, worms can cause losses in the form of decreased calories and protein and blood loss. In addition to the loss of nutrient reduction, worms can hinder physical development, intelligence and work productivity, and can also reduce endurance and immunity so that they are susceptible to disease and other infections.

The results showed that intestinal worm infections in children under five with malnutrition (malnutrition) in Kupang district were $42 \%$. This research is not much different from research conducted on elementary school children in Southwest Sumba district as much as $40 \%$ (Paun et al., 2019). Based on the results of the examination, the most common type of worms found was Ascaris lumbricoides (74.9\%). When compared with the results of the study by Mau Fridolina (2017), the highest prevalence was A. Lumbricoides infection, 28.5\%, followed by T. Trichiura infection, 5.9\%. This is because children under five in Kupang Regency generally regularly receive anti-helminth drugs. from the Tarus puskesmas even though there are still infected children. This is due to the lack of personal hygiene that is not paid attention to such as not wearing footwear when doing outdoor activities, not washing hands and feet after direct contact with the ground, the habit of playing on the ground, nails that are rarely cut and direct contact with playmates so that worm eggs are easy. move. One of the intestinal worm infections is STH. This is in line with the research of Annisa et al. (2018) showing positive that infected with STH, most of them have a malnutrition status, which is $62.1 \%$. From the results of the Chi-square statistical test, it was found that $p$ value $=0.037(p<0.05)$ and $\mathrm{OR}=2.765(95 \%$ CI: 1.147-6.662) so it can be seen that statistically there is a significant relationship between STH infection and nutritional status.

Various factors influence the high rate of intestinal worm infections in children under five, including environmental factors and personal hygiene. The results showed that garbage dumps in families of children with intestinal worm infections generally did not exist, the results of statistical tests were $p$ value $0.004<\alpha 0.05$, so there was an effect of landfills on the incidence of intestinal worm infections in children under five. Likewise, the means of collecting waste in general, there is no family, the results of the statistical test are p value $0.032<\alpha 0.05$, so there is an effect of waste disposal facilities on intestinal worm infections in children under five. Landfills and waste development facilities are at risk of intestinal worm infection in children under five, this is due to the unavailability of landfills and waste disposal advice so that both dry and alkaline garbage are disposed of carelessly resulting in lots of flies and then the flies transfer the worm eggs to the food that will be eaten by toddlers.

Individual hygiene factor is a factor of children's behavior that also affects intestinal worm infections in children under five with poor nutrition. behavior according to psychology is the response or reaction of a person to external stimuli (stimulus). Meanwhile, health behavior is all the activities of a person, both observable and unobservable, which are related to health and illness in the maintenance and improvement of health.

Individual health status is closely related to their behavior, the better the behavior related to health, the better their health status will be. Clean and Healthy Behavior Households are obtained from households where all members have a clean and healthy lifestyle. The results showed that the habit of children under five who were infected with intestinal worms defecating partly (47.1\%) in any place, the results of statistical tests were $p$ value $0.030<\alpha 0.05$, so there was an effect of defecation habits on intestinal worm infections in children under five. The habit of toddlers using footwear is generally not / rare, the result of statistical test is p value $0.026<\alpha 0.05$, so there is an effect of the habit of using footwear on the incidence of intestinal worm infection in children under five. The eating habits of children under five are $100 \%$ cooked, as is the habit of drinking $100 \%$ cooked water. The habit of children under five generally inserts their fingers into their mouths (sucking their fingers), the results of statistical tests are $\mathrm{p}$ value $0.002<\alpha 0.05$, so there is an effect of the habit of putting their fingers in the mouth on the incidence of intestinal worm infections in children under five. Likewise, the nail conditions of children under five, are generally dirty and long, the results of the statistical test $p$ value $0.004<\alpha 0.05$, so there is an effect of nail conditions on intestinal worm infections in toddlers. According to research by Jalaluddin (2009) in Lhokseumawe, it was shown that nail hygiene had a significant effect on the incidence of worm infection. Obtained $p$ value $=0.005$ with an OR value of 2.730, where students who have poor nail hygiene have a 2.7 times chance of being infected with worms 
compared to students who have good nail hygiene. While the research of Farisdan et al (2013) in Banjarbaru City showed contradictory results, namely that the habit of washing hands was statistically not significant to worm infection with a value of $\mathrm{p}=0.632$, but seen from the OR value of 1.7 , it was found that nail hygiene was a factor. the risk of worm infection, where dirty nails have a 1.7 times higher risk of suffering from worms than clean nails. In general, snack habits in children under five, the statistical test results of p value $0.005<\alpha 0.05$, so there is an effect of eating habits on intestinal worm infections in toddlers. Furthermore, the family habit of not closing cooked food, statistical test results $\mathrm{p}$ value $0.007<\alpha 0.05$, so there is an effect of the habit of closing food on the incidence of intestinal worm infections in children under five. The habit of snacking children bought at a food stall is open so that flies can easily transfer worm eggs from other media to snacks that are sold. The model of the incidence of intestinal worm infections in children under five with children with nutritional problems, based on the results of the study, shows that the habits of snacking children and how to store food openly result in young flies transferring worm eggs from other media to the food the child wants to eat.

\subsection{Research Ethics}

The implementation of this research begins with explaining the research objectives and submitting requests to respond to children under five and asking for approval to become respondents, without giving names and maintaining confidentiality and submitting the approval of the research ethics committee of the Health Polytechnic of the Ministry of Health, Kupang.

\section{Conclusion}

1). The prevalence of intestinal worm infection in children under five in Kupang district is $42 \%$. The highest type of worm (74.3\%) was Asc. Lumbricoides.

2). Environmental factors that affect intestinal worm infections are garbage dumps and waste disposal facilities.

3). Behavioral factors that affect intestinal worm infection in children under five are the habit of defecating, the habit of using footwear, the habit of doing activities with the soil, the cleanliness of the nails, the habit of sucking the thumbs / fingers, the habit of eating snacks and how to store cooked food.

4). The model of incidence of intestinal worm infection in children under five with nutritional problems is influenced by the habit of eating snacks and how to store food that has been cooked simultaneously.

\subsection{Recommendation}

1). The Health Office (department) / Local Government Clinic (Puskesmas) needs to carry out health promotion by giving up on personal hygiene to prevent intestinal worm infections in children under five

2). The community should always provide garbage disposal facilities and waste disposal facilities so that they do not become a medium for vectors (flies) to reproduce. Limit children to snacks and always cover cooked food.

\section{Competing Interests Statement}

The authors declare that there are no competing or potential conflicts of interest.

\section{References}

Annisa, S., Dalilah, \& Chairil, A. (2018). Correlation of Soil Transmitted Helminths (STH) Infection with Nutritional Status in 200 Public Elementary School Students, Kemasrindo Village, Kertapati District, Palembang City (Hubungan Infeksi Cacing Soil Transmitted Helminths (STH) dengan Status Gizi pada Siswa Sekolah Dasar Negeri 200 Kelurahan Kemasrindo Kecamatan Kertapati Kota Palembang). Sriwijaya Medical Magazine (Majalah Kedokteran Sriwijaya), 50(2).

Irianto, K. (2009). Soil Transminted Helmints (STH) Infection with Children's Learning Prevention SDN 169 in Gandus Village, Gandus District (Infeksi Soil Transminted Helmints (STH) dengan Preustasi belajar Anak SDN 169 di kelurahan Gandus Kecamatan Gandus).

Jalaluddin. (2009). The Influence of Environmental Sanitation, Personal Hygiene and Characteristics of Children on Worms Infection in Elementary School Students in Blang Mangat District, Lhokseumawe City (Pengaruh Sanitasi Lingkungan, Personal Hygiene dan Karakteristik Anak Terhadap Infeksi Kecacingan Pada Murid Sekolah Dasar di Kecamatan Blang Mangat Kota Lhokseumawe) (Tesis, Medan, University of North Sumatera).

Health Ministry of the Republic of Indonesia (Kemenkes RI). (2013). Basic Health Research (Riset Kesehatan Dasar; RISKESDAS). Jakarta: Research and Development Agency Health Ministry of the Republic of Indonesia (Balitbang Kemenkes RI). 
Health Ministry of the Republic of Indonesia (Kemenkes RI). (2018). Basic Health Research (Riset Kesehatan Dasar; RISKESDAS). Jakarta: Research and Development Agency Health Ministry of the Republic of Indonesia (Balitbang Kemenkes RI).

Mau, F. (2017). Prevalence and Intensity of Soil-Tansmitted Helminth Infections Among.

Olin, W., Paun, R., \& Rindu, Y. (2019). Behavior Model of Prevention of Soil Transmitted Helminth (STH) in Elementary School Student in the District of Northwest Sumba. International Journal of Medicine, Health and Food Sciences, 3(1), 1-9.

Paun, R., Olin, W., \& Tola, Z. (2019). The Impact of Soil Transmitted Helminth (STH) towards anemia case in elementary school student in the District of Northwest Sumba. Global Journal of Health Science, 11(5), 117-117. https://doi.org/10.5539/gjhs.v11n5p117

Ramayulis, R., Triyani, K., Sri, I., \& dan Nur'aini, S. R. (2018). Stop Nutritional Problems With Nutrition Counseling, Spread Plus (Stop Masalah Gizi Dengan Konseling Gizi, Penebar Plus) (Penebar Swadaya).

Rawina dan, M. (2012). Efforts to Eradicate Worms in Elementary Schools (Upaya Pemberantasan Kecacingan di Sekolah Dasar), University of Indonesia, Jakarta.

\section{Copyrights}

Copyright for this article is retained by the author(s), with first publication rights granted to the journal.

This is an open-access article distributed under the terms and conditions of the Creative Commons Attribution license (http://creativecommons.org/licenses/by/4.0/). 